\title{
Local Wisdom of Tahlī and Tunggu Kubur Practices in Death Custom among The Malays in Malaysia
}

\author{
Muhammad Yusri Yusof @, Salleh,* Mohd Anuar Ramli \\ Department of Fiqh \& Usul, Academy of Islamic Studies, Universiti Malaya, Kuala Lumpur \\ *Corresponding author: yusri613@uitm.edu.my
}

\section{Article history}

Received: 2020-05-03 Received in revised form: 2021-03-03 Accepted: 2021-03-04 Published online: 2021-06-30

\begin{abstract}
Custom plays a significant role in any organised community as well as in the building of mutual harmony and avoiding conflicts. The establishment of a custom is the result from the interaction between the wisdom of the local intellectuals and its environment to meet the needs of the local community. The Malay community is a group that is rich with traditions, ranging from the birth customs, marriage and death. Basically, in the practice of the Malay customs there exists two polemics in which forms two opposing schools of thought. First is the fundamentalist that rejects most local customary practices. Second, is the traditionalist as they only accept the valid customs practised in society and reject invalid customs. These opposing views can be seen in various customary practices, for example in the death custom or ceremonies such as tablil (recital ceremony for the deceased), talqin (recital for the deceased during burial), and tunggu kubur (grave waiting). Therefore, this study focuses on exploring the practice of tablil (recital ceremony for the dead) and tunggu kubur (grave waiting) through the concept of the local wisdom from the perspective of the principles of Islamic jurisprudence. To achieve these objectives, this study deploys an eclectic approach and interview method. The collected qualitative data were analysed thematically. The results of the study showed that there are elements of local wisdom behind these practices. In the Malay community, tablil (recital ceremony for the deceased) is a form of psychological and emotional support as well as a communal approach to the family of the deceased while the practice of tunggu kubur (grave waiting) is an approach to protect the burried corpses from thefts and mystical activities. Therefore, the local wisdom implied behind the practices are valid and hence, included in the category of accepted customary practices.
\end{abstract}

Keywords: local fiqh, valid custom, death custom, local wisdom, Malay 


\subsection{INTRODUCTION}

Human beings are noble creations created by Allah SWT, and granted the with the title of being the khalifah on earth. This noble entitlement was bestowed by Allah SWT to allow man kind to rule and manage the earth with wisdom and just. Human beings are honoured, not only when they are alive, but also in the afterlife (Shahdan, 2017). It can be observed through the practice of Sunnah on how Islam honours human bodies even after they die, especially by the religious and pious people. Honouring the deceased is encouraged in Islam. According to the Sunnab (practices of the Prophet), the honouring moment starts during the agony of one's death until the burial ceremony (Nurrahmah, 2014). This fundamental practice has been followed by Muslims all over the world. Although in the Malaysian context, the local Muslims followed most of the Islamic burial process or the Sunnah (practices of the Prophet), yet it is seen that the implementation of the local's customs have been inserted within the burial process. In fact, these cultural elements, routines and local practices which were inserted were not associated with the Quran and Sunnah (practices of the Prophet). These cultural elements are closely related to the local ingenuity and intelligence resulting from the interaction between the locals and its environment.

Generally, the term local genius suggested by Muhammad Yusri \& Mohd Anuar (2020) is formed based on the combination of daily experiences, local knowledges, inspirations and guidance partially from religion. On the contrary, the concept of local wisdom proposed by Muhammad Yusri \& Mohd Anuar (2020) is described as a 'tacit' knowledge that is only understood and introduced by the people of their local origins, they have their own local wisdom to solve problems faced by the people. Commonly the term of local wisdom is somehow restricted to only matters involving cultural matters. The application of local wisdom in solving cultural related matters are executed through deep observation, thinking capabilities, local knowledges and Petua (tips) that are appropriate with its environment and situation. Muhammad Yusri \& Mohd Anuar (2020) further elaborate that,in further understanding this concept of local wisdom it is classified into three tiers; 1) the highest tier, which involves deep thinking capabilities or the usage of materials that are separate from the basic function of society 2) the Second, tier; is when the use of the form of thought and material that consists of basic functions and finally 3 ) the lowest tier; the use of the form of thought and material borrowed from other civilizations, and adapted to the needs of the community.

In the Malay setting, Islam has laid death as the final journey for any living being. It is described as the finishing line of the worldly life, thus began a spiritual transfer from the world of the living to the afterlife. The concept of spiritual transfer is understood by the leaving of the deceased human body behind and the Rub (soul) to the afterlife. In paying the final tribute for the deceased, the Malay society has its own custom of managing the dead without neglecting the Islamic aspects such as the Sunnah (practices of the Prophet) behind. The Malays basically adhere to the guidelines of managing the deceased based on the Sunnab (practices of the Prophet) of the Prophet SAW. Other than the Sunnah (practices of the Prophet), there are also additional practices and elements based on the needs of the situation (during managing the deceased) and natural ingredients which can easily be found in the Malay world. For example, according to the Sunnah (practice of the Prophet), one of the ways is to bathe the deceased is by using water mixed with the daun bidara (jujube leaves) and kapur barus (Camphor). There are other places which use coconut oil to soften the joints of the deceased and the coconut coir to remove any forms of dirt from the body during the bathing ritual. In different regions of Malaysia, the Malay uses turmeric to remove odours as well as to refresh the body and diminish the pale look of the skin. There are mortuary managers who use the daun bidara (Jujube leaves) to replace soap in bathing the deceased. The daun 
inai (henna leaves) are often used to replace the daun bidara (jujube leaves) to refresh the deceased (Muhammad Yusri et.al, 2017).

Basically, in the practice of the Malay custom as mention above exists two polemics which form two opposing schools of thought. First is the fundamentalist group that rejects most local customary practices. Second, the traditionalist group that accepts the valid customs practised in society and reject invalid customs. These opposing views can be seen in various customary practices, for example in the death custom and ceremonies of tablil (recital ceremony for the deceased), talqin (recital for deceased during burial), and tunggu kubur (grave waiting). Therefore, this study aims to focus on exploring the practice of tablil (recital ceremony for the deceased and tunggu kubur (grave waiting) through the concept of local wisdom from the perspective of the principles of Islamic jurisprudence.

\subsection{LITERATURE REVIEW}

\subsection{Concept of Local Wisdom}

Local wisdom is a form of deep and creative thinking as it contains the implicit values in the practice. Explicit values can be understood only by looking at the practice, but the implicit value requires deep observation and understanding to appreciate the hikmah (wisdom) contained herein. Implicit values are usually unkwon and difficult to understand from an external view point as it needs guidance and narration from previous generations to fully understand its relevance. Among the examples of local wisdom in the Malay society is the bathing of the deceased using coconut milk, was practiced by the Bajau community in Sabah. Explicitly, the coconut milk is a substance used for cooking. Among the functions of the coconut milk besides making mouthwatering dishes, the coconut milk is also used to soften the meat. Therefore, the function of the coconut milk is also implicitly used in the process of bathing the deceased, in order to $\mathrm{n}$ softens the stiff joints. It can also replace the function of daun bidara (jujube leaves) which are very difficult to obtain in Sabah. Since, the coconut is easier to obtained, thus through deep observation and the plant's functions reflects the local element of wisdom is scientifically validated for its effective use (Syamsul Azizul Marinsah et. al, 2020).

Meanwhile, the term local genius refers to a series of practical knowledge which, if interpreted, is defined in two meanings; first, the cleverness of the local community in daily routine and second is through inheritment from previous generations (Nunung \& Muslim, 2016). However, the difference between local wisdom and local genius is that local genius is comprised of explicit values alone without any relation to the implicit values (Wahyu Lestari, 2000). Instances of the local genius in managing the deceased, is the use of natural ingredients such as the akar sintok (sintok root) to remove dirt from the body of the deceased because the Malays are familiar with the function of this root in which its effectiveness to clean dirt and stain. This function of the akar sintok (sintok wood) was well known before the use of soap as an alternative (Muhammad Yusri et.all, 2017). Second, local genius is associated with the skills of combining logical and mystical elements in everyday life (Kamilah \& Setyani, 2018). This term is used by the western and eastern scholars in describing the ability of the people of Archipelago in everyday life to interact and relying on their believes towards God and other supernatural beliefs such as ghosts, spirits, demons, tree spirits, sea spirits, forest spirits (Ruastiti, 201; Bahtiar et. al, 2011). The differences are; local wisdom contains logical elements and scientifically tested, meanwhile, local genius does not align with logical thinking and have a strong dependency towards mysticism (Muhammad Yusri \& Mohd Anuar, 2020a). 
The concept of local genius is also a separate term from local wisdom as local wisdom refers to a series of information and knowledge available to the people within the society. These series of information, when practiced, will develop to integrate either into local genius or local wisdom. For example, Malaysians are recorded by Western scholars as a society full of mystical practices and are known for their diverse practices of local knowledge and mystical practices. One of them is the love charm (ilmu pengasih) as written in ancient books (Muhammad Ali Zulfakar, 1980; Harun Mat Piah, 2006). Roikhwanphut Mungmachon (2012) when discussing about local knowledge and local wisdom, it is characterized that some local knowledge as, first, knowledges that can sustain the society as an indicator of daily practices such as history, values, culture, traditions and rules. Second, the knowledge used for work such as work skills, religious knowledge, self-motivation and knowledge of personal and environmental health. Third, the knowledge of tranquillity, that is, the knowledge that human beings feel calm in life such as knowledge gained from the news, sports, entertainment and so on.

\subsection{Disagreements Between the Traditionalists and Fundamentalists in Islamic Perspective}

The development of the foundation laid down by the Sunnah (practices of the Prophet) have raised contradiction among intellectuals. There are two groups, the first is known as the fundamentalists, they who restrict the interpretation of the nusus as-Syari'ab (al-Quran and alSunnah) only to the Quran and Sunnah (practice of the Prophet), disagree with the interference of cultural practices and traditions in Thädah (prayers and obligations to God). Any additions from the cultural and traditional elements are regarded as heretics. This group describes that a tradition which has never been practiced by the Sunnah (practices of the Prophet) cannot be implemented and must be eradicated. The fundamentalists call for a return to the true teachings of Islam and consider these cultures and traditions a deliberate addition and burdensome to society. This group is seen open to the questions of mazhab (schools of thought) and call on the tajdid (the reform of Islamic teaching and practice) of thought and practice.

The second group is the traditionalists who accepts culture and tradition as one of the sources of law. This group believes accepts the non-conflicting results of thinking and culture with nusus as-Syari'ah (al-Quran and al-Sunnah) and to practice them in everyday life. Authentic 'urf (custom) is accepted to be practiced and considers to accept traditions and cultures that are not contradictory to Syari'ah (Islamic rules) and to include them in the classification of bid'ah hasanah (a good religios innovation). The traditionalists believe in the perfection of a practice including in the custom of death as a form of final tribute which should be done in the best manner and full of honour. This group accepts authentic elements of local wisdom as acceptable form of 'urf (custom) and include them as bid'ah hasanah (a good religios innovation) as permitted in Islam. These two groups keep on arguing with each other in the struggle to defend their own streamline. Both groups are highly intellectual and have distinctive argument regarding this matter. This conflict will never stop as every group has different perspective on how they should respond to arising legal issues. For this while, the conflict between these two groups centres at the discussion on the nusus al-Syariah (AlQuran and Sunnah) are related to the stand of Quran and Sunnah (practices of the Prophet). The discussion on the reason of implementing a custom and tradition is very limited. It is rare to find argument on the theory of local wisdom with detail interpretation on the reason and the necessity of implementing the practice. 


\subsection{Disagreements on the Tahlīl (recital ceremony for the deceased) Practice}

Tablil (recital ceremony of the deceased) from the etymological view comes from the root word or masdar (A noun that is derived from a verb) of hallala, yuballilu, tablilan which brings the meaning of reciting the word là ila ha illa Alläh (There is no deity except Allah). The tablìl (recital ceremony for the deceased) in terms of this practice among the people of the Malay Archipelago carries a meaning referring to a group of people uttering diviker (Chanting to praise Allah) and praying together asking forgiveness for the deceased. (Hafiz, 2021). This tablil ceremony begins with a recitation of short surah (Chapters in the Qoran), such as al-Fätihah, al-Ikbläs, and al-Nās. Then the recitation is continued with several verses from the Quran, salawat (Praise to the Prophet Muhammad PBUH), and dziker (Chanting to praise Allah) related to asking forgiveness from Allah SWT and getting closer towards Allah SW'T. The ceremony ends with Dua' (prayers) and amin (Used at the end of a prayer or a statement to express assent or approval) by the guests. In the Malay setting, the tablil (recital ceremony for the deceased) ceremony is accompanied with food provided by the family of the deceased (Sholikhin, 2016). The traditionalists accept and argue towards the fundamentals; First of all, tablil (recital ceremony for the deceased) is considered as an inherited practice for all Muslims around the world, not only in the area of archipelago, also by some Muslims in Arab peninsular including Yemen, Turkey, Syria, and so on. It is considered as a form of knowledge-based activity and a special reading for the dead in the form of prayer so that the deceased is forgiven by Allah SWT. Secondly, there are general arguments from the Quran and Sunnab in which allows it to be practiced (Sholikhin, 2017):

\section{Hadith of the Prophet SAW:}

'Recite towards the deceased among you with the words of là ilā ha illa Alläh.' (HR. Muslim, no. 915).

2. The verse in the Quran as Allah SWT mentioned:

"And those who came After them say : "Our Lord! Forgive us, and our brethren Who came before us Into the Faith, And leave not, In our hearts, Rancour (or sense of injury) Against those who have believed. Our Lord! Thou art Indeed Full of Kindness, Most Merciful. " (Quran 59: $10)$.

The traditionalists also believe that the food provided by the family of the deceased is encouraged in Islam because there are various hadith (record of the traditions or sayings of the Prophet Muhammad (PBUH)) in general demonstrating the purpose of preparing food for alms and glorifying guests (Abdul Somat, 2017). Meanwhile, the fundamentalists believed that tablil (recital ceremony for the deceased) is a form of bid'ah (religious innovation) which is never been practiced by the Prophet Muhammad (PBUH), the prophet's companions and the Tabi in (are the generation of Muslims who followed the Companions of the Prophet Muhammad). They have rejected the concept of sending and passing reward to the deceased and assuming that this act was emerged from the bid'ah (religious innovation) and khilaf sunnah (contradict with Sunnah). This group believes what is being taught by Islam that to fulfil the Sunnab of the Prophet (PBUH) is to pray for the dead with good wishes. This group is also inclined to a view that the food provided for the guests is not neccessary and does not recommended by the Prophet (PBUH). What was taught by the Prophet (PBUH) was to provide food for the deceased's family. Such gatherings and tablil ceremony are considered to be part of Prophet's prohibition of wailing. They also use the arguments from the reference books of al-Shafi iyyah to ban the kenduri arwah (feast in remembering the deceased) and consider it as an act of bid'ah (religious innovation) (Anshary, 2013). 


\subsection{Disagreements on the Tunggu Kubur (grave waiting) Practice}

Tunggu kubur is commonly practiced in Kedah and in other east coast states such as Kelantan and Terengganu. Usually, it is practiced for seven days from the first day of the burial. This practice is done with two or three people reciting al-Quran in a small hut provided near the grave. They will take turn reciting the Quran with the intervals of an hour or two hours for each turn. This practice aims at avoiding unwanted things happen to the body and to pass reward of reciting the Quran to the deceased. Usually throughout these seven days of the grave waiting, people who wait will recite the Quran in turns and finish reciting the whole Quran at least once (Humaizi, 2018). The differences between these two groups basically focus on the practice of grave waiting and reciting Quran near the grave. The traditionalists see it as non-contradictory to the Sunnah based on different levels of hadith. This group holds onto the hadith that encourages the recitation of Yäsin, al-Fätibah, and the final part of surah al-Baqarah at the grave. They also rely on the hadith of the Prophet (PBUH) to place a date palm frond on a grave. They also hold fast to the opinion that allows the recitation of the Quran near the grave and to make it beneficial for the deceased based on Shafi'iyyah (I2, 2018; I3, 2018).

Moreover, Qädhi Iyadh and al-Qarafi from the Maliki school of thought also supported the view based on the justification that the deceased gains barakah (blessings) from the recitation of the Quran. Imām Ahmad bin Hanbal also allows, while Imam Malik and Abu Hanifah views it as makruh, as it is not found in the Sunnah of the Prophet (PBUH) (Anshary, 2013). The fundamentalists have rejected this practice by arguing that the practice was not practiced by the Prophet (PBUH), the Prophet's companions and the Täbi in. They also view that the bädith related to the recitation of Yassin during the death is considered as $d h \bar{a}$ if (hadith which does not fulfil the requirement of sahih or hassan). A number of 'ulama' also consider this hadith as maudbü' (the text of which goes against the established norms of the Prophet's sayings, or its reporters include a liar) As the fundamentalists proposed (Anshary, 2013):

"Reciting the verses of Yàsinn when a person is dying with the purpose to enhance the process, is it an act of murder, so now many people believe that Sūrah Yāsīn can kill a person.”

This group also holds firm on the ijtihad (independent interpretation) of some scholars including Albani who views Yäsin and the Quran when a person is dying are considered khiläf sunnah and there was no solid support from the Quran and Sunnah. This act is categorized as bid'ah (religious innovation) (Anshary, 2013).

\subsection{RESEARCH METHODOLOGY}

In order to further discern the subject of tablil (recital ceremony for the deceased) and tunggu kubur (grave waiting) and its correspondence to the concept of local wisdom and Islamic perspective, this research deploys an eclectic approach in which utilizes the concept of local wisdom and qualitative approach such as the interview method. Selected informants are interviewed to generate their perspectives about ideas, opinions and experiences pertaining to research topic. The qualitative data collected were analysed thematically.

\subsection{RESULTS AND DISCUSSION}

\subsection{Local Wisdom in The Practice of Tahli1}

Tablil (recital ceremony for the deceased) and kenduri arwab (feast in remembering the deceased) are practices borrowed from traditions and cultures of the Arabs especially from Yemen and Syria. They were brought in by preachers who arrived at the Malay Archipelago, thispractice 
were also also introduced to the local preachers to abolish the practice of superstition that was practiced during the pre-Islamic tradition. The practice of borrowing from foreign cultures is then integrated into the cultural context of the Malay community and undergoes changes in accordance to the culture of the local community. The practice of tablil (recital ceremony for the deceased) among the people of Malay Archipelago is loaded with local wisdom in the form of theory and practice. It has explicit and implicit function in its practice (Agustia, 2013). Explicitly, the Malays considered death as the final journey of a human being in the world. It is a process of moving from the real world to the world after. Hence, the Malay community is very concerned with the custom of the dead and guarantees the completion of rituals and customs as the final form of tribute to the deceased (Muhammad Yusri \& Mohd Anuar, 2019). This last honour is accomplished in the best form. The body is not only sent to Allah SWT but also to ensure that the soul of the deceased is forgiven for every sin he has committed when he was alive. Thus, through tablil (recital ceremony for the deceased) is an alternative way of asking forgiveness and blessing from Allah SWT.

The Malay community believes in the concept, that it might be a person in the crowd whose prayer is answered as people is distinguished based on his piety. The Malays are well known for the concept of helping which becomes the pillars in the life of the community, including during attending a funeral, as people do not only manage the deceased collectively, together they also ask forgiveness from Allah SWT (Abdul Karim, 2017). Implicitly, tablil (recital ceremony for the deceased) has a number of local wisdom elements. First, it is a mechanism of alleviating the feeling of sadness for the family of the deceased. It is a form of moral support emerged from social interactions among the people in the community. This kind of support can be observed when the family, neighbours and friends come together at the house of the deceased usually at night after the 'isya' prayer as a way to fill the feeling of lost and emptiness. A respected person in the community will lead the recitation of driker (Chanting to praise Allah) and prayer together with other visitors and this kind of action helps to reduce the gloom of the family members. Second, most of the time, money spend for the tablil (recital ceremony for the deceased) ceremony does not come from the deceased himself, however, it comes from the family members as an act of almsgiving in the form of food and hope to pass the reward of this act to the deceased. The Malays believe this kind of almsgiving benefits the deceased in a long run because food builds human body, it comes together with reward for the deceased (I2, 2018; I3, 2018).

Third, in the Malay custom, it is forbidden to cook and send food for the family of the deceased as it can lead to misunderstanding, therefore, they prefer to offer things or money, known as sedekah kepala mayat (the almsgiving of the deceased's head). It is a form of financial support towards the family of the deceased. The money and materials given to the family are used to prepare the food for kenduri arwah (feast in remembering the deceased). The Malay community is known for the concept of khairät and tumpang kenduri (money given as present during ceremony). Close relationship among the Malays when giving financial and material support can be observed during the process of tablil (recital ceremony for the deceased) and kenduri arwah. This is a kind of social support which can alleviate sadness and lift up the burden carried by the family (Suwito, 2015). Fourth, tablil (recital ceremony for the deceased) and kenduri arwah (feast in remembering the deceased) has become a mechanism for the process of asking forgiveness from the society which have been committed by the deceased throughout his life. It is also the time that allows the deceased to fullfil his responsible and rights upon other people who are still alive. This opportunity is used by the family to ask the community to forgive the deceased and pay the debt on behalf of him. They also fulfil the responsibility of the deceased should have done when he was alive through the information given by the guests who come to the tablil (recital ceremony for the deceased) 
ceremony and kenduri arwah (feast in remembering the deceased). It also becomes a place to strengthen the relationship among the family of the deceased, which is actually coincides with the claim of certain badith of the Prophet Muhammad (PBUH) (I1, 2018; I2, 2018).

Fifth, tablil (recital ceremony for the deceased) and kenduri arwah (feast in remembering the deceased) is a ceremony that invites the community to do good deeds by reciting the Quran and doing charity. Aside from praying for the deceased, it also reminds the people regarding death and to constantly prepare for it (Muhazzab, 2017). People also believe that the spirit of the dead will return on certain night such as the first, third, seventh and forty, as well as the hundredth day of his death (Mohd Sholikin, 2018). Such belief is not parallel to the teaching of the Quran and Sunnab and it is contradictory to the purpose of carrying out tablil (recital ceremony for the deceased). This practice is not accepted and it only applies to lower class people who does not understand the philosophy behind the practice of tablil (recital ceremony for the deceased) (Syihabuddin, 2013).

\subsection{Local Wisdom in The Practice of Tunggu Kubur}

The practice of grave waiting has some explicit and implicit elements of the local wisdom. Explicitly, it can be considered as collective effort which exists in a community with the aim to pray for the deceased and to seek forgiveness from Allah SWT. The reward gain throughout the seven-day of reciting the Quran near the grave is an effort of passing the reward to the deceased. Some people also believe that if someone waits at the grave, it can delay the torment of the grave and the attendance of the angel of Munkar and Nakir. (Mukhsin, 2017). Such beliefs are still common in the community and it becomes a defamatory to the practice of grave waiting. The deviation of this purpose may be due to the absence of oral tradition to transfer to the basic function of this practice (I1, 2018; I2, 2018).

Secondly, for implicit functions it is a way to protect the body of the deceased from undesirable things. The minyak pengasib (love charm) of the famous minyak dagu (chin oil) in the Malay community is taken from the oil of the corpses that are roasted by fire. The Minyak dagu is harvest and charmed with a spell and given to the shaman (Mustaqim, 2012). Other than that, the tuju-tuju is a form of witchcraft in which needs the shroud from a newly buried corpse as a material to perform the black magic successfully. The grave cult followers also worship the grave of the pious people and grave with new corpse wishing for something (Muhammad Yusri \& Mohd Anuar, 2020b). There are also black magic practioner as they seek body parts such as the head, hair, nails and the skin of the corpses that are later chanted and used as amulet for mystical, black magic and superstitious purposes. However, these practices seem to become depleted in this modern era (I3, 2018; I2, 2018). Thirdly, due to the lack of tools, geographical location and soil structure, the practice of grave waiting was introduced in the past to ensure that the body of the deceased was not taken away by animals such as dogs, pigs and bears. Previously, people did not have the proper tools and workforce as they lived in scattered areas, therefore the graves did not reach its correct depth and measurement in comparison to today's setting. Hence, grave waiting was practiced to also to hinder the threat from animals as the soil of the grave had not fully and completely harden. For certain areas, the imperfect condition of the grave soil has exposed the dead to certain animals. Therefore, as a form of honour, the previous community took turn waiting at the grave while reading al-Quran seeking forgiveness and passing the reward to the deceased (I2, 2018; I3, 2018).

\subsection{CONCLUCION}

Local wisdom exists in the death custom or burial ceremony among the Malay community. It reflects the ingenuity and wisdom resulting from the efforts of the community in solving problems raised in the community at a particular time. This wisdom has been transferred from generations Page | 46 
to generations. The transference of this elements of local wisdom is largely happened, yet the reason behind implementing a practice remains unexplained. This study is part of an attempt to reveal the wisdom behind the practice of death custom and also to elucidate the practices based on the principle of Islamic jurisprudences. For local wisdoms which meet the features of principle of Islamic jurisprudences are accepted as a valid custom, meanwhile the elements that contradicted are rejected and considered as an invalid custom.

\section{List of Reference}

Abdul Karim (2017). Makna Ritual Kematian Dalam Tradisi Islam Jawa. Sabda, 12(2), 1-11.

Abdul Somad (2017). 37 Masalah Popular. Pekan Baru: Penerbit Tafaqquh.

Agus Efendi (2014). Implementasi Kearifan Budaya Lokal Pada Masyarakat Adat Kampung Kuta Sebagai Sumber Pembelajaran IPS. Sosio Didaktika, 1(2), 212-217.

Agustia Diana Artika Sari (2017). Selametan Kematian Di Desa Jaweng Kabupaten Boyolalli. Haluan Sastra Budaya, 2(1): 147-161.

Al-Maany Li Kulli Rasm Ma'na (2020). Ta'rif wa Ma'na Tahlil. Access on 23 December 2020, from https://www.almaany.com/ar/dict/ar-ar/tahlil.

Anshary (2013). Fiqh Kontroversi Beribadah Antara Sunnah Dan Bidaah. Bandung: Tafakur.

Aslan (2017). Nilai-Nilai Kearifan Lokal Dalam Budaya Pantang Larang Suku Melayu Sambas. Jurnal Imu Usuluddin, 16 (1), 11-20.

Atkinson, P. A. \& Coffey, A. (1997). “Analysing Documentary Realities', in Qualitative researcb: Theory, Method and Practice, ed. Silverman. London: Sage.

Bowen, G, A, (2009). Document Analysis as a Qualitative Research Method. Qualitative Research Journal, 9(2), $27-43$.

Hafiz Za'farani (2021). Majlis Tablilan: Polemik. Sepanjang Zaman Huraian Lengkap Konsep Bidaah di Sisi Abli Sunnah Wal Jamaah. Kuala Lumpur: Dar Fitri Resources.

Informant 1 (I1) (2018). Local Wisdom in the Death Custom of the Bajau. Interview. 29th July 2018.

Informant 2 (I2)(2018). Local Wisdom in Tablil. Interview. 12 th December 2018.

Informant 3 (I3) (2018). Local Wisdom in the Practice of Tunggu kubur. 13 th December 2018.

Mohd Sholikhin (2017). Ritual Kematian Islam Jawa: Pengarub Tradisi Lokal Indonesia Dalam Ritual Kematian Jawa. Yogyakarta: Penerbit Narasi.

Mohd Sholikhin (2018). Ritual Dan Tradisi Islam Jawa: Ritual-Ritual Tradisi Tentang Kehamilan, Kelabiran, Pernikahan Dan Kematian Dalam Kebidupan Seharian Masyarakat Islam Jawa. Yogyakarta: Penerbit Narasi.

Muhammad Ali Zufaqar (1980). Perdukunan Melayu. Ipoh: Pustaka Muda.

Muhammad Yusri Yusof@ Salleh, Rahimin Affandi Abd. Rahim, Faridah Yahaya, Paiz Hassan, Abd. Munir Mohamed Noh \& Mohd Zahirwan Halim Zainal Abidin (2017). Funeral Management In The Malay World: Local Knowledge And Practices. Journal of Applied Environmental and Biological Sceinces, 1(IS), 72 77.

Muhammad Yusri Yusof@ Salleh \& Mohd Anuar Ramli (2019). Local Wisdom in Agony of Death among Malay-Muslim Society in Malaysia. International Journal of Academic Research in Social Science, 9(9), 426-436.

Muhammad Yusri Yusof @ Salleh \& Mohd Anuar Ramli (2019a). Pentakrifan Kearifan Tempatan: Suatu Sorotan. Jurnal Melayu, 19(2), 175-188,

Page | 47 
Muhammad Yusri Yusof @ Salleh \& Mohd Anuar Ramli (2019b). Kearifan Tempatan dalam Adat Kematian Masyarakat Melayu dari Perspektif Uruf. Jurnal of Fatwa Management and Research, 21(1), 21-37.

Muhazzab Said (2017). Revitalisasi Tradisi Masalo Pada Upacara Kematian Di Desa Baebunta Dalam Perspektif Dakwah. Pelita: Journal of Social Religion Research, 2(2), 1-16.

Mukhsin Patriansyah (2017). Makna Dan Nilai Simbolis Upacara Kematian Yang Dilaksanakan Oleh Masyarakat Desa Seleman Kabupaten Kerinci Jambi. Jurnal Sains desain dan Budaya, 2(1), 1-6.

Mustaqim Pabbajah (2012). Religuisitas dan kepercayaan masyarakat bugis makassar. Jurnal al-Ulum, 12(1), 397-418.

Nurrahmah Hana (2014). Tradisi Ziarah Kubur Studi Kasus Perilaku Masyarakat Muslim Kerawang Yang Mempertahankan Tradisi Ziarah Makam Syeh Quro Kampung Prubata Karawang. Disertasi Sarjana: Universiti Islam Negeri Syarif Hidayatullah.

Nunung Unayah \& Muslim Subariman. 2016. Identifikasi Kearifan Lokal dalam Pemberdayaan Komunitas Adat Terpencil. Penerbit Akatiga: Bandung.

Roikhwanphut mungmachon (2012). Knowledge And Local Wisdom: Community Treasure. International Joumal of Humanities and Sosial Sciences, 2 (13), 174-181.

Ruastiti, Ni Made (2011). The Concept of Local Genius In Balinese Performing Arts. Mudra journal of Art and Cuture, 26 (3), 241-245.

Suwito, Agus Seriyanto \& Arif Hidayat (2015). Tradisi Dan Ritual Wong Islam Jawa. Ibda' Jurnal Kebudayaan Islam, 13(2), 197-216.

Syahdan (2017). Ziarah Perspektif Kajian Budaya. Jumal Studi Agama dan Masyarakat, 13(1), 65-99.

Syihabuddin (2013). Tradisi Upacara Kematian Pada Masyarakat Nahdiyyin Dalam Tinjauan Agama Dan Adat. Al-Adyan, 7(1), 1-27.

Syamsul Azizul Marinsah, Asmiaty Amat \& Aisyah Tamby Omar (2020). Ritual Perubatan Tradisional Etnik Bajau Di Sabah: Analisis Dari Perspektif Hukum Islam. MANU Jurnal Pusat Penataran Ilmu dan Babasa, 31 (1), 73-95. 